Article

\title{
Evaluation of Natural and Factitious Food Sources for Pronematus ubiquitus on Tomato Plants
}

\author{
Marcus V. A. Duarte ${ }^{1, *(\mathbb{D}}$, Dominiek Vangansbeke ${ }^{1}{ }^{\circledR}$, Juliette Pijnakker $^{1}$, Rob Moerkens ${ }^{1}$, Alfredo Benavente ${ }^{1}$, \\ Yves Arijs ${ }^{1}$, Ana Lizbeth Flores Saucedo ${ }^{2}$ and Felix Wäckers ${ }^{1}$ \\ 1 Biobest Group N.V., Isle Velden 18, 2260 Westerlo, Belgium; Dominiek.vangansbeke@biobestgroup.com (D.V.); \\ juliette.pijnakker@biobestgroup.com (J.P.); Rob.Moerkens@biobestgroup.com (R.M.); \\ Alfredo.Benavente@biobestgroup.com (A.B.); Yves.Arijs@biobestgroup.com (Y.A.); \\ Felix.Wackers@biobestgroup.com (F.W.) \\ 2 Department of Molecular Phytopathology and Mycotoxin Research, Georg-August-Universität Göttingen, \\ 37073 Göttingen, Germany; anaflores.0591@gmail.com \\ * Correspondence: Marcus.Duarte@biobestgroup.com
}

check for

updates

Citation: Duarte, M.V.A.; Vangansbeke, D.; Pijnakker, J.; Moerkens, R.; Benavente, A.; Arijs, Y.; Saucedo, A.L.F.; Wäckers, F. Evaluation of Natural and Factitious Food Sources for Pronematus ubiquitus on Tomato Plants. Insects 2021, 12, 1111. https://doi.org/10.3390/ insects12121111

Academic Editors: Koichi Goka and Enrico De Lillo

Received: 10 November 2021

Accepted: 9 December 2021

Published: 13 December 2021

Publisher's Note: MDPI stays neutral with regard to jurisdictional claims in published maps and institutional affiliations.

Copyright: (c) 2021 by the authors. Licensee MDPI, Basel, Switzerland. This article is an open access article distributed under the terms and conditions of the Creative Commons Attribution (CC BY) license (https:/ / creativecommons.org/licenses/by/ $4.0 /)$.
Simple Summary: Biocontrol practitioners have increasingly released generalist predators to control a variety of greenhouse pests. In this study, the effects of alternative food sources on the oviposition rate and the population dynamics of the mite Pronematus ubiquitus were assessed. The alternative food sources were selected among those the mite may encounter or be applied to the tomato crop.

Abstract: Pronematus ubiquitus (McGregor) is a small iolinid mite that is capable of establishing on tomato plants. Once established, this mite has been shown to control both tomato russet mite, Aculops lycopersici (Tryon) (Acari: Eriophyidae), and tomato powdery mildew (Oidium neolycopersici L. Kiss). In the present study, we explored the effects of a number of alternative food sources on the oviposition rate in the laboratory. First, we assessed the reproduction on food sources that $P$. ubiquitus can encounter on a tomato crop: tomato pollen and powdery mildew, along with tomato leaf and Typha angustifolia L. In a second laboratory experiment, we evaluated the oviposition rate on two prey mites: the astigmatid Carpoglyphus lactis L. (Acari: Carpoglyphidae) and the tarsonemid Tarsonemus fusarii Cooreman (Acari: Tarsonemidae). Powdery mildew and C. lactis did not support reproduction, whereas tomato pollen and T. fusarii did promote egg laying. However, T. angustifolia pollen resulted in a higher oviposition in both experiments. In a greenhouse trial on individual caged tomato plants, we evaluated the impact of pollen supplementation frequency on the establishment of P. ubiquitus. Here, a pollen addition frequency of every other week was required to allow populations of $P$. ubiquitus to establish.

Keywords: biological control; alternative food; Tydeoidea

\section{Introduction}

In contrast to the long-held conviction that specialist natural enemies are required to guarantee effective pest control [1], biocontrol practitioners have been increasingly releasing generalist predators to control a several of greenhouse pests [2,3]. Generalist predators possess several interesting properties, which explain this shift: (1) Generalist predators feed on several pest species. A single generalist predator species thus simultaneously affects populations of multiple pest species [4,5]. (2) They are more likely to be able to exploit alternative food sources, such as pollen, fungi, or plant sap [6,7], which may enable them to build up populations in the absence of prey food [8-12]. (3) Generalist predators are generally easier and cheaper to mass-produce [13]. For example, phytoseiid predatory mites can be mass-produced on factitious astigmatid prey mites [14,15]. As a result, generalist phytoseiid predatory mites, such as Amblyseius swirskii (Athias-Henriot), Neoseiulus californicus (McGregor), and Neoseiulus cucumeris (Oudemans), are now among 
the most commercialized arthropod biocontrol agents worldwide [16,17], and have been introduced in a wide range of crops, mostly in protected cultivation. In protected crops such as pepper and cucumber, phytoseiids successfully control thrips, whiteflies, and spider mites [18-23]. Unlike on cucumber and pepper, phytoseiid predatory mites have difficulties building up populations on tomato crops, even when having access to prey food shown to be suitable in laboratory trials, such as the tomato russet mite (TRM), Aculops lycopersici (Tryon) (Acari: Eriophyidae), and several species of whiteflies [24-26]. The inability of Phytoseiidae to establish on tomato plants is attributed to the presence of glandular trichomes, which hamper their movement, especially those found in the young leaves [27,28]. Unlike the larger phytoseiid predators, smaller mites from the family Iolinidae (superfamily Tydeoidea) are not affected by the presence of glandular trichomes and can successfully establish on tomato plants [29,30]. For example, Pronematus ubiquitus (McGregor) is a small $(<300 \mu \mathrm{m})$ omnivorous mite that feeds on a variety of plant-derived food sources, such as pollen and plant sap [3,31]. This predatory mite also feeds on small prey food, such as Eriophyid [32] and Tetranychid mites [32,33]. In addition to plant-provided food sources and prey, these mites are also known to feed on fungi [34,35]. Recently, this predatory mite was found to effectively control two key problems on tomato crops: TRM, A. lycopersici, and powdery mildew (Oidium neolycopersici L. Kiss) [3]. This predatory mite can be pre-established and build up large populations by supplementing tomato plants with Typha sp. pollen [3,31].

The nutritional value of food sources can influence the biological parameters of an organism. When on the tomato crop, P. ubiquitus can encounter food sources such as tomato pollen and conidia of powdery mildew [3]. Other Iolinidae predators have also been reported to feed on fungi $[36,37]$. However, the influence of a specific food source on the biological parameters of a mite species can also be affected by its origin. Therefore, this study aimed to select the food supplement that can optimize the reproduction of one or two lines of P. ubiquitus, collected in Belgium and The Netherlands.

Several food sources have been tested to support the establishment of generalist predators in greenhouse crops [23,38,39], including pollen [8,40-42], frozen eggs of Ephestia kuehniella Zelle [23], and Artemia sp. cysts [12,43]. Here, we explored the potential of two species of prey mites for supporting a population of P. ubiquitus on a tomato crop, namely the dried-fruit mite Carpoglyphus lactis (L.) (Acari: Carpoglyphidae) and Tarsonemus fusarii Cooreman (Acari: Tarsonemidae). The former is a conventionally used astigmatid prey mite that can support populations of phytoseiid predatory mites on crops [44-47]. In addition, several Tarsonemidae species were found to be suitable prey mites for phytoseiids [48-50]. Finally, based on the outcome of the feeding experiments in the laboratory, a greenhouse trial was conducted to assess the optimal application frequency of Typha pollen for the establishment of P. ubiquitus on tomato plants.

\section{Materials and Methods}

\subsection{Mites and Plants}

Two lines of P. ubiquitus were collected in Belgium (Merelbeke) and The Netherlands (Venlo), from blackberry (Rubus sp.) and grape (Vitis sp.) plants, respectively. These lines were mass-reared in the production facilities of Biobest N.V. on a diet consisting of $T$. angustifolia pollen (Nutrimite ${ }^{\mathrm{TM}}$ ). Tarsonemus fusarii was produced on Aspergillus oryzae fungus grown on rice flakes (De Halm B.V.) as described by Vangansbeke et al. [49]. A mixture of yeast flakes and bran was used to produce C. lactis. Both T. fusarii and C. lactis were produced in climate chambers at $22 \pm 1{ }^{\circ} \mathrm{C}, 80 \pm 5 \%$ relative humidity, and a L16:D8 photoperiod.

Tomato plants (cv. 'Marinice') (De Ruiter Seeds, Bleiswijk, The Netherlands) were sown in trays. One week after germination, tomato seedlings were transplanted to $1 \mathrm{~L}$ pots with potting soil (Greenyard Horticulture, Ghent, Belgium). Plants were subsequently grown in the Greenlab research facilities of Biobest $\left(16.5-22{ }^{\circ} \mathrm{C}\right.$ and $70 \pm 10 \%$ relative humidity). 


\subsection{Experiment 1: Pronematus ubiquitus Strain Comparison}

In the first experiment, we assessed oviposition of two P. ubiquitus populations, collected in Belgium and The Netherlands. Each involved a single adult female P. ubiquitus, randomly selected from the mass-rearing units, which was then placed on a $4 \mathrm{~cm}^{2}$ tomato leaf section on top of moist cotton within a $5 \mathrm{~cm}$ Petri dish arena. These leaf discs had Typha angustifolia ad libitum as a food supplement once at the start of the experiment. Each female was allowed to lay eggs for four days. At this time, the total number of eggs laid by each female was counted. These arenas were kept at $23 \pm 1{ }^{\circ} \mathrm{C}, 70 \pm 10 \%$ relative humidity, and a L16:D8 photoperiod. Each treatment contained 12 replicates. The total oviposition was analyzed using generalized linear models (GLMs) with a Poisson error distribution [51]. In addition, contrasts among predators were determined with general linear hypothesis testing (function glht of the package lsmeans in R, Lenth 2016).

\subsection{Experiments 2 and 3: Oviposition of P. ubiquitus on Alternative Foods}

In these two experiments, the P. ubiquitus line collected in Belgium was studied for its oviposition ability by applying the same method as that of Experiment 1. For Experiment 2 , the food sources offered for the mites were: clean tomato leaf, tomato leaf infected with powdery mildew, tomato leaf with tomato pollen, and tomato leaf with T. angustifolia pollen. Tomato pollen was obtained from flowers collected from tomato plants (cv. 'Marinice') (De Ruiter Seeds, The Netherlands) in the Greenlab facilities. Flowers were dried for $72 \mathrm{~h}$ at room temperature $\left(20-23{ }^{\circ} \mathrm{C}\right)$ and relative humidity $(30-50 \% \mathrm{RH})$. Thereafter, pollen could be removed easily from the flowers before being frozen at $-18^{\circ} \mathrm{C}$. Experiment 3 had clean tomato leaf, tomato leaf with T. angustifolia pollen as per the previous experiment, and tomato leaf with the prey mites $T$. fusarii or C. lactis. For both prey mites, a mix of all life stages was offered. All food sources were offered ad libitum once at the start of the experiment. Each treatment in Experiment 2 had 12 replicates and Experiment 3 had ten replicates per treatment. The total oviposition of Experiment 2 was compared among treatments with a generalized linear model (GLM) with a Poisson error distribution [51]. For Experiment 3, the comparison among treatments was also performed with a GLM. However, the distribution for this case was a quasi-Poisson error distribution due to the overdispersion of the data. In addition, contrasts among predators were determined with general linear hypothesis testing (function glht of the package lsmeans in R [52]).

\subsection{Experiment 4: Frequency of Application of Typha Angustifolia for Pre-Establishing P. ubiquitus}

For this experiment, a cage trial was performed on individual tomato plants $\mathrm{cv}$. Merlice (De Ruiter Seeds, Bleiswijk, The Netherlands) to determine the ideal frequency of application of T. angustifolia pollen to promote P. ubiquitus (Belgium line) population growth Cylindrical cages were used for this experiment having a diameter of $40 \mathrm{~cm}$ and height of $110 \mathrm{~cm}$. At the start of the experiment the tomato plants had five to six leaves and height of $32 \mathrm{~cm}$. Four frequencies of pollen application were evaluated in comparison with control without pollen supplement. Five treatments were arranged in a randomized complete block design with five replicates: P. ubiquitus without pollen supplement; P. ubiquitus + pollen supplement weekly; P. ubiquitus + pollen every two weeks; P. ubiquitus + pollen every three weeks; P. ubiquitus + pollen every four weeks. Fifty mixed stages of P. ubiquitus were introduced per plant at the first week of the experiment and an additional 100 one week later. A dose of $0.1 \mathrm{~g}$ of $T$. angustifolia pollen was evenly distributed on each plant with a soft hair brush over the entire plant at the frequency defined for each treatment. This amount of pollen per application corresponds to the recommended amount of $500 \mathrm{~g} / \mathrm{ha}$ for supplementary feeding of phytoseiid predatory mites [40,41]. The first assessment was carried out two weeks after the first introduction of P. ubiquitus. Assessments involved counting the number of $P$. ubiquitus mobiles found on fifteen individual $7 \mathrm{~cm}^{2}$ leaflet sections per plant under a stereoscopic microscope. These leaflets were collected at random through the entire plant. These counts were repeated for five consecutive weeks following the second release. The number of mites was compared among treatments with a linear 
mixed-effects model (LME) with treatment and time as fixed factors and plant identity as a random factor to correct for repeated measures. Non-significant interactions and factors were removed from the model. In addition, contrasts among predators were determined with general linear hypothesis testing (function glht of the package lsmeans in R [52]). All analyses were performed using the statistical software R 3.6.1 [53].

\section{Results}

\subsection{Experiment 1: Pronematus ubiquitus Strain Comparison}

No difference was observed in the reproduction capacity of P. ubiquitus collected in Belgium and The Netherland (Figure 1: GLM, $\chi^{2}=0.34 ; p=0.56$ ).

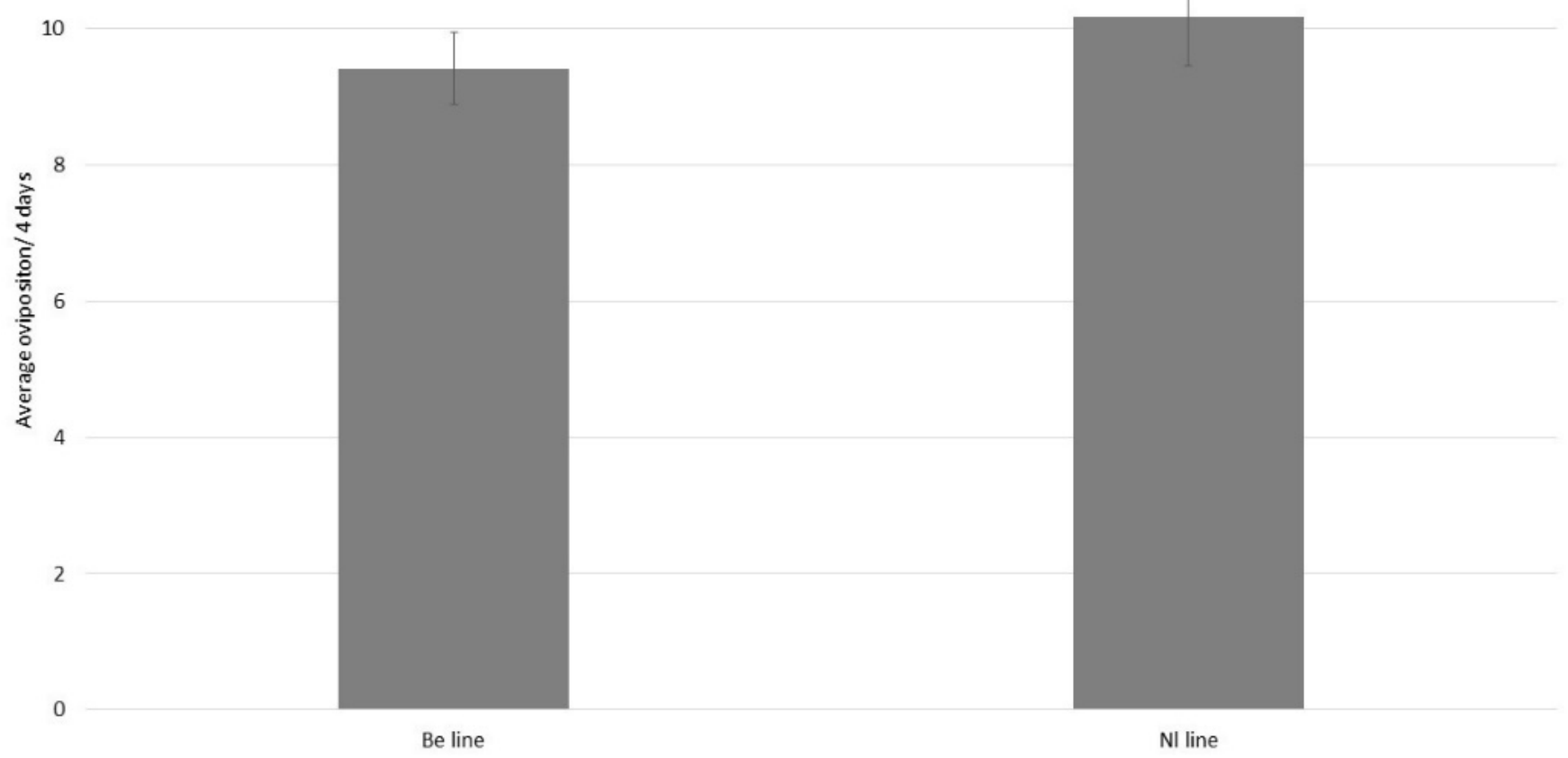

Figure 1. Average of the total oviposition for four days (mean $\pm \mathrm{SE}$ ) for P. ubiquitus either collected in Belgium (Be line) or The Netherlands ( $\mathrm{Nl}$ line) on a tomato leaf with the addition of T. angustifolia pollen. There were no significant differences between the two lines (GLM, $\left.\chi^{2}=0.34 ; p=0.56\right)$.

\subsection{Experiment 2: Oviposition of P. ubiquitus on Naturally Occurring Food Sources on Tomato Crops}

The different food sources significantly impacted the oviposition of P. ubiquitus (Figure 2: GLM, $\chi^{2}=100.8 ; p<0.001$ ). The highest oviposition was recorded when $T$. angustifolia was offered as a food source, followed by tomato pollen (Figure 2). When mites had access to powdery mildew, only a marginal improvement in the oviposition was recorded (Figure 2). The lowest oviposition was observed when the tomato leaf had no additional food source (Figure 2).

\subsection{Experiment 3: Oviposition of P. ubiquitus on Factitious Food Sources}

The oviposition of P. ubiquitus was influenced by the different food sources (Figure 3: GLM, $F_{2,39}=100.8 ; p<0.001$ ). Similar to the previous experiment, T. angustifolia induced the highest oviposition rate, followed by the tarsonemid prey mite T. fusarii (Figure 3). The prey mite C. lactis did not show any additional effect on the reproduction of P. ubiquitus compared to the tomato leaf alone (Figure 3). 


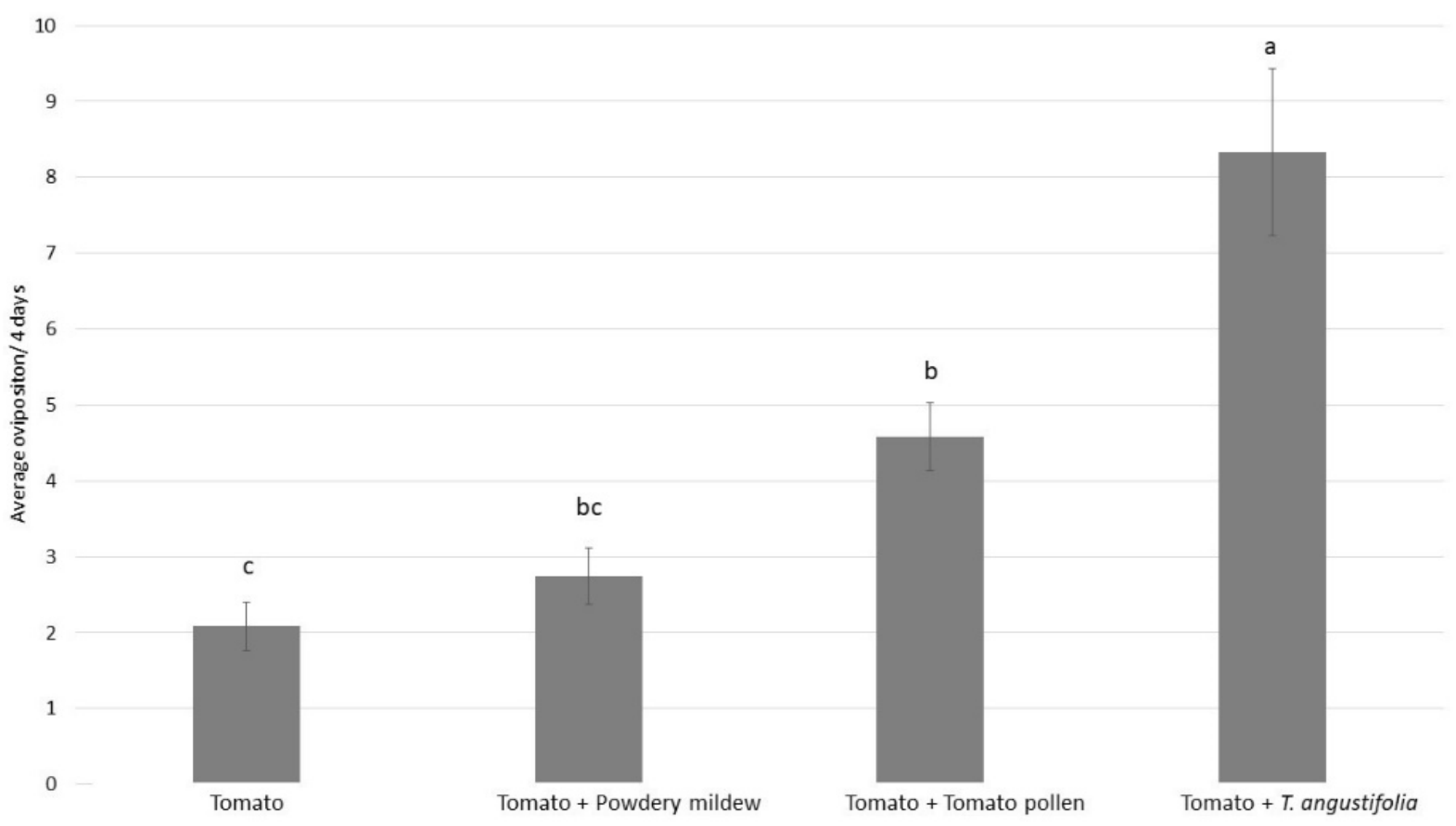

Figure 2. Average of the total oviposition over the course of 4 days (mean $\pm \mathrm{SE}$ ) for P. ubiquitus on tomato alone, tomato with powdery mildew, tomato with tomato pollen, and tomato and T. angustifolia. Different letters above the bars denote significant difference among treatments (contrast after GLM, $p<0.05$ ).

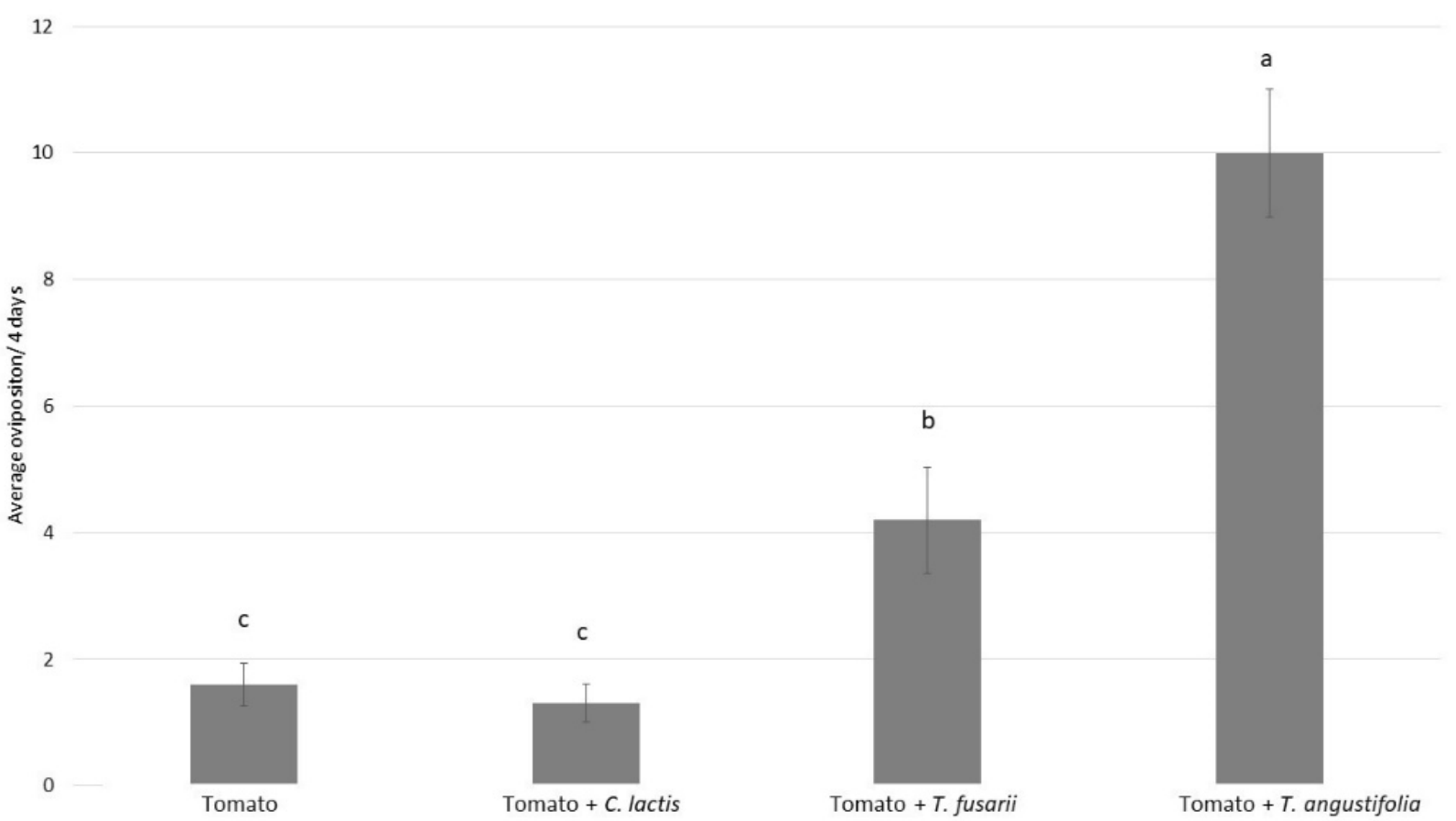

Figure 3. Average total oviposition over four days (mean $\pm \mathrm{SE}$ ) for P. ubiquitus on tomato alone, tomato with C. lactis, tomato with T. fusarii and tomato with T. angustifolia. Different letters above indicate differences among treatments.

3.4. Experiment 4: Frequency of Application of T. angustifolia for Pre-Establishing P. ubiquitus

There was a significant interaction between the frequency of application of $T$. angustifolia and time on the population of P. ubiquitus (Figure 4: LME, $\chi=102.9, p<0.001$ ). Weekly application of pollen resulted in the highest number of $P$. ubiquitus, followed by applications every other week (Figure 4). However, the application of pollen every three or 
four weeks did provide an initial benefit; this benefit was not sustained during the entire trial (Figure 4).

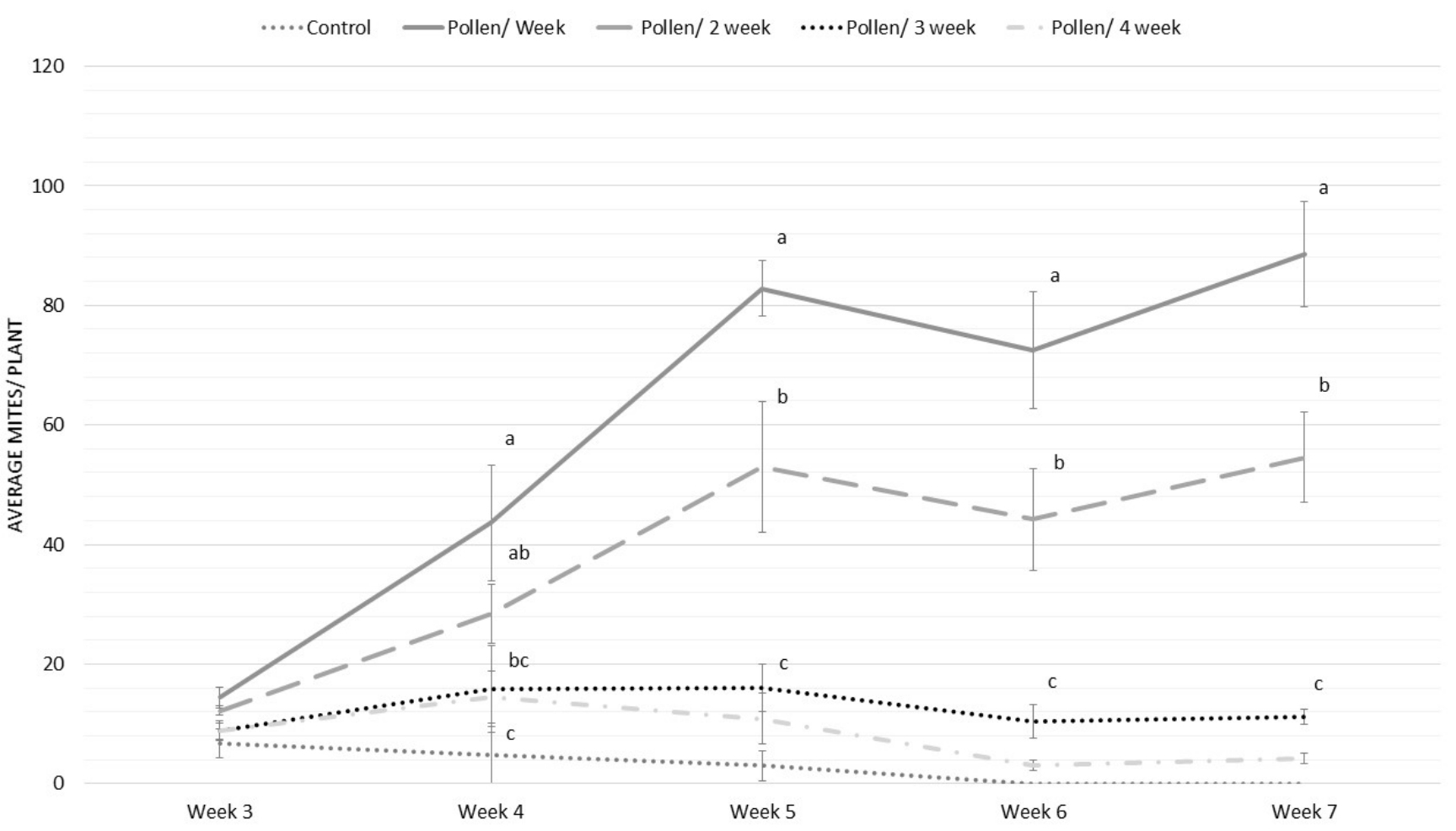

Figure 4. Population dynamics of P. ubiquitus (mean $\pm \mathrm{SE}$ ) when fed with a different T. angustifolia frequency. Control plant did not receive pollen. Pollen/week represents weekly pollen addition, Pollen/2 week means pollen addition every other week, Pollen/3 week means pollen application every 3 weeks, and Pollen/4 week means one pollen application every four weeks. Different letters above the data points denote significant differences among treatments during that week (contrast after LME, $p<0.05)$.

\section{Discussion}

In this study, natural and factitious food sources were evaluated for the predatory mite P. ubiquitus. For phytoseiid predatory mites, differences in life history traits have occasionally been observed between different strains of the same species [54,55]. Here, we did not observe differences in egg laying on T. angustifolia pollen between the two lines of $P$. ubiquitus collected from Belgium and The Netherlands. This result is to be expected because both collection sites were close and no morphological differences were observed between strains (de Vis and Ueckermann, personal communication). We opted to undertake the subsequent trials using only the Belgium strain because we had worked with this strain longer and did not have any reason to believe that the strains would behave differently on the other food sources.

Overall, Typha angustifolia pollen was found to be the most suitable food source for reproduction compared to a diet consisting of fungus (i.e., powdery mildew) or prey mites. These results confirm the findings of previous studies showing pollen to be an excellent food for Iolinidae predatory mites, such as P. ubiquitus and the closely related Homeopronematus anconai (Baker) (Acari: Iolinidae) [35,37]. However, tomato pollen was found to be inferior as compared to T. angustifolia pollen. Only a few predatory mites were observed on tomato plants when tomato pollen was the only food source (i.e., no T. angustifolia pollen was added). This confirms that pollens derived from different plant species can differ greatly in their nutritional quality for predatory mites [6,56]. Furthermore, other pollen features such as grain size, structure, and exine thickness determine the suitability of a pollen food source [57]. However, both pollen species tested here have a diameter of ca. $20 \mu \mathrm{m}[57,58]$. Therefore, size cannot explain the observed differences in reproductive output. 
Although tomato is a self-pollinating plant, the agitation of the anthers (e.g., by pollinators or by wind) facilitates shedding of the pollen grains. As a result, tomato pollen tends to be confined in flowers and only a limited amount of pollen will drop down to the leaves below to serve as food for the mites. Tomato growers introduce bumblebee hives in the greenhouse to facilitate crop pollination. By engaging in so-called "buzz-pollination", bumblebees promote the release of tomato pollen from the anthers [59,60], resulting in optimal fruit set and yield [58]. In this study, no bumblebees were present during the trial as plants were confined individually in cages. It remains to be investigated whether bumblebee presence would allow pollen to drop down more due to the buzz-pollination, thereby supporting populations of P. ubiquitus on the tomato crop. Finally, pollen quality and quantity depend on the tomato cultivar [61,62], which has been shown to influence bumblebee behavior in tomato crops [63]. Similarly, the reproductive and population growth performance of P. ubiquitus may be affected by the tomato cultivar itself via plant feeding.

Tydeid mites are well known to engage in fungivory. For example, Orthotydeus lambi (Baker) was found to reduce the incidence and severity of grape powdery mildew, Uncinula necator (Schwein.) Burrill on both potted and field-grown vine plants [64,65]. Recently, Pijnakker et al. [3] reported the potential of P. ubiquitus to control powdery mildew on tomato plants. The reproductive output of P. ubiquitus on powdery mildew in our laboratory trial was lower than that on a pollen diet and similar to that of the tomato leaf-only treatment. Similarly, Hessein and Perring [37] reported that the presence of the fungus Cladosporium cladosporioides (Fres.) de Vries on grape leaf arenas yielded the same low number of $H$. anconai as compared to a grape leaf-only treatment. In contrast, high numbers of mites were retrieved when grape leaf arenas were supplemented with Typha sp. pollen. Although feeding on powdery mildew conidia and mycelia was observed, the exact mechanisms through which $P$. ubiquitus controls powdery mildew on tomato, as reported in the study of Pijnakker et al. [3], remains to be elucidated. Being a plant feeding mite, indirect plant-mediated effects might be triggered by feeding on the plant tissue, similar to the observations in other plant-feeding natural enemies [66]. Further study is required to investigate whether the biocontrol effect of $P$. ubiquitus on powdery mildew is due to feeding on the fungus, plant-mediated effects, or a combination thereof.

Food supplementation has become a standard practice in biocontrol programs in several crops to support the pre-establishment of generalist predators (Messelink et al. 2014; Pijnakker et al. 2021; Benson and Labbé 2021). Astigmatid prey mites are a relatively cheap alternative food source explored as a food supplement on crops, mainly to feed phytoseiid predatory mites [2]. The reproduction of P. ubiquitus on C. lactis in our study was negligible. Hence, C. lactis will most likely not be suitable for supporting Pronematus populations in a tomato crop. By comparison, the tarsonemid prey mite, T. fusarii, allowed reproduction in P. ubiquitus, albeit to a lesser extent than T. angustifolia pollen. Body size is an important factor determining the outcome of prey-predator interactions $[67,68]$ and may explain why smaller tarsonemid prey mites would be more suitable than the larger $C$. lactis. Typha angustifolia pollen was clearly superior to the other foods tested, and although pollen would be the preferred food supplement based on our laboratory trials and previous results, it may nevertheless be interesting to test combinations of different food sources for rearing or maintaining on the crop. Mixing two diets was reported to yield higher reproduction than offering single diets in predatory mites [69-71].

Based on the results of the laboratory trials, we tested the impact of T. angustifolia pollen application frequency on P. ubiquitus establishment on tomato plants. Our results clearly show that pollen needs to be supplemented at least every other week to allow a good population build-up of P. ubiquitus. Populations can be maintained using less frequent applications (every three or four weeks). For the phytoseiid predatory mite Iphiseius degenerans Berlese on cucumber, van Rijn et al. [40] found that 14-day-old Typha latifolia recollected from the crop still allowed immature development and reproduction, although at a lower rate compared to freshly applied pollen. 


\section{Conclusions}

In summary, we showed that T. angustifolia pollen is a good food source to sustain the reproduction of P. ubiquitus. Application of T. angustifolia pollen allows the build-up of $P$. ubiquitus populations on tomato plants when applied at a frequency of at least once every two weeks at a dose rate of $500 \mathrm{~g}$ of pollen per hectare. Tomato pollen was found to support the reproduction of P. ubiquitus, but to a far lesser extent than Typha pollen. Finally, our laboratory trials indicated tarsonemid prey mites, such as $T$. fusarii, show potential to support populations of P. ubiquitus, whereas the larger astigmatid prey mite C. lactis was not suitable.

Author Contributions: Conceptualization: M.V.A.D., D.V., A.L.F.S. and F.W.; methodology: M.V.A.D., D.V., J.P., A.B. and R.M. formal analysis: M.V.A.D. and D.V.; writing: M.V.A.D., D.V., J.P., A.L.F.S., Y.A. and F.W.; investigation: M.V.A.D., D.V., J.P. and A.B.; supervision: F.W. All authors have read and agreed to the published version of the manuscript.

Funding: This research received no external funding.

Institutional Review Board Statement: Not applicable.

Data Availability Statement: The raw data are available from the corresponding author upon request.

Acknowledgments: We would like to thank Peggy Bogaerts and Ilse Jacobs for their technical support in greenhouse trials. We also thank Eddie Ueckermann and Raf de Vis for the identification of the mites. This work was undertaken alongside the Flanders Agency for Innovation and Entrepreneurship VLAIO project 'BALTO'.

Conflicts of Interest: The authors declare no conflict of interest.

\section{References}

1. Symondson, W.O.C.; Sunderland, K.D.; Greenstone, M.H. Can Generalist Predators be Effective Biocontrol Agents? Annu. Rev. Entomol. 2002, 47, 561-594. [CrossRef] [PubMed]

2. Messelink, G.J.; Bennison, J.; Alomar, O.; Ingegno, B.L.; Tavella, L.; Shipp, L.; Palevsky, E.; Wäckers, F.L. Approaches to conserving natural enemy populations in greenhouse crops: Current methods and future prospects. BioControl 2014, 59, 377-393. [CrossRef]

3. Pijnakker, J.; Moerkens, R.; Vangansbeke, D.; Duarte, M.; Bellinkx, S.; Benavente, A.; Merckx, J.; Stevens, I.; Wäckers, F. Dual protection: A tydeoid mite effectively controls both a problem pest and a key pathogen in tomato. Pest Manag. Sci. 2021, 78, 355-361. [CrossRef]

4. Messelink, G.J.; van Maanen, R.; van Steenpaal, S.E.; Janssen, A. Biological control of thrips and whiteflies by a shared predator: Two pests are better than one. Biol. Control 2008, 44, 372-379. [CrossRef]

5. Leman, A.; Ingegno, B.L.; Tavella, L.; Janssen, A.; Messelink, G.J. The omnivorous predator Macrolophus pygmaeus, a good candidate for the control of both greenhouse whitefly and poinsettia thrips on gerbera plants. Insect Sci. 2020, 27, 510-518. [CrossRef]

6. Goleva, I.; Zebitz, C.P.W. Suitability of different pollen as alternative food for the predatory mite Amblyseius swirskii (Acari, Phytoseiidae). Exp. Appl. Acarol. 2013, 61, 259-283. [CrossRef]

7. Mendoza, J.E.; Balanza, V.; Cifuentes, D.; Bielza, P. Genetic improvement of Orius laevigatus for better fitness feeding on pollen. J. Pest Sci. 2021, 94, 729-742. [CrossRef]

8. Leman, A.; Messelink, G.J. Supplemental food that supports both predator and pest: A risk for biological control? Exp. Appl. Acarol. 2015, 65, 511-524. [CrossRef]

9. Wäckers, F.L. Suitability of (Extra-) Floral Nectar, Pollen, and Honeydew as Insect Food Sources. In Plant-Provided Food for Carnivorous Insects: A Protective Mutualism and Its Applications; Cambridge University Press: Cambridge, UK, 2005; pp. 17-74.

10. Duarte, M.V.A.; Venzon, M.; Bittencourt, M.C.D.S.; Rodriguez-Cruz, F.A.; Pallini, A.; Janssen, A. Alternative food promotes broad mite control on chilli pepper plants. Biocontrol 2015, 60, 817-825. [CrossRef]

11. Kumar, V.; Xiao, Y.; McKenzie, C.L.; Osborne, L.S. Early establishment of the phytoseiid mite Amblyseius swirskii (Acari: Phytoseiidae) on pepper seedlings in a Predator-in-first approach. Exp. Appl. Acarol. 2015, 65, 465-481. [CrossRef]

12. Vangansbeke, D.; Nguyen, D.T.; Audenaert, J.; Gobin, B.; Tirry, L.; De Clercq, P. Establishment of Amblyseius swirskii in greenhouse crops using food supplements. Syst. Appl. Acarol. 2016, 21, 1174-1184. [CrossRef]

13. McGregor, R.; Crisp, K.; Castiglia, C. Feeding lifestyles of the Phytoseiidae revisited: Searching for a factitious rearing host for Neoseiulus fallacis (Acari: Phytoseiidae). BioControl 2020, 65, 593-599. [CrossRef]

14. Calvo, F.J.; Knapp, M.; van Houten, Y.M.; Hoogerbrugge, H.; Belda, J.E. Amblyseius swirskii: What made this predatory mite such a successful biocontrol agent? Exp. Appl. Acarol. 2015, 65, 419-433. [CrossRef] [PubMed] 
15. Massaro, M.; Montrazi, M.; Melo, J.W.S.; de Moraes, G.J. Small-Scale Production of Amblyseius tamatavensis with Thyreophagus cracentiseta (Acari: Phytoseiidae, Acaridae). Insects 2021, 12, 848. [CrossRef] [PubMed]

16. Knapp, M.; van Houten, Y.; van Baal, E.; Groot, T. Use of predatory mites in commercial biocontrol: Current status and future prospects. Acarologia 2018, 58, 72-82. [CrossRef]

17. Van Lenteren, J.C. The state of commercial augmentative biological control: Plenty of natural enemies, but a frustrating lack of uptake. BioControl 2012, 57, 1-20. [CrossRef]

18. Ramakers, P.M.J. Biological control of Thrips tabaci (Thysanoptera: Thripidae) with Amblyseius spp. (Acari: Phytoseiidae). Bull. SROP 1980, 3, 203-207.

19. Messelink, G.J.; van Steenpaal, S.E.F.; Ramakers, P.M.J. Evaluation of phytoseiid predators for control of western flower thrips on greenhouse cucumber. BioControl 2006, 51, 753-768. [CrossRef]

20. Palevsky, E.; Walzer, A.; Gal, S.; Schausberger, P. Evaluation of dry-adapted strains of the predatory mite Neoseiulus californicus for spider mite control on cucumber, strawberry and pepper. Exp. Appl. Acarol. 2008, 45, 15-27. [CrossRef] [PubMed]

21. Calvo, F.J.; Bolckmans, K.; Belda, J.E. Control of Bemisia tabaci and Frankliniella occidentalis in cucumber by Amblyseius swirskii. BioControl 2011, 56, 185-192. [CrossRef]

22. Calvo, F.J.; Bolckmans, K.; Belda, J.E. Biological control-based IPM in sweet pepper greenhouses using Amblyseius swirskii (Acari: Phytoseiidae). Biocontrol Sci. Technol. 2012, 22, 1398-1416. [CrossRef]

23. Labbé, R.M.; Gagnier, D.; Shipp, L. Comparison of Transeius montdorensis Acari: Phytoseiidae) to other phytoseiid mites for the short-season suppression of western flower thrips, Frankliniella occidentalis (Thysanoptera: Thripidae). Environ. Entomol. 2019, 48, 335-342. [CrossRef]

24. Park, H.-H.; Shipp, L.; Buitenhuis, R.; Ahn, J.J. Life history parameters of a commercially available Amblyseius swirskii (Acari: Phytoseiidae) fed on cattail (Typha latifolia) pollen and tomato russet mite (Aculops lycopersici). J. Asia-Pac. Entomol. 2011, 14, 497-501. [CrossRef]

25. Paspati, A.; Rambla, J.L.; Gresa, M.P.L.; Arbona, V.; Gómez-Cadenas, A.; Granell, A.; González-Cabrera, J.; Urbaneja, A. Tomato trichomes are deadly hurdles limiting the establishment of Amblyseius swirskii Athias-Henriot (Acari: Phytoseiidae). Biol. Control 2021, 157, 104572. [CrossRef]

26. Vervaet, L.; De Vis, R.; de Clercq, P.; van Leeuwen, T. Is the emerging mite pest Aculops lycopersici controllable? Global and genome-based insights in its biology and management. Pest Manag. Sci. 2021, 77, 2635-2644. [CrossRef] [PubMed]

27. Drukker, B.; Janssen, A.; Ravensberg, W.; Sabelis, M.W. Improved control capacity of the mite predator Phytoseiulus persimilis (Acari: Phytoseiidae) on tomato. Exp. Appl. Acarol. 1997, 21, 507-518. [CrossRef]

28. Van Haren, R.J.; Steenhuis, M.M.; Sabelis, M.W.; De Ponti, O.D. Tomato stem trichomes and dispersal success of Phytoseiulus persimilis relative to its prey Tetranychus urticae. Exp. Appl. Acarol. 1987, 3, 115-121. [CrossRef]

29. Kawai, A.; Haque, M.M. Population dynamics of tomato russet mite, Aculops lycopersici (Massee) and its natural enemy, Homeopronematus anconai (Baker). Jarq-Jpn. Agr. Res. Q. 2004, 38, 161-166. [CrossRef]

30. Aysan, E.; Kumral, N.A. Tritrophic relationships among tomato cultivars, the rust mite, Aculops lycopersici (Massee) (Eriophyidae), and its predators. Acarologia 2018, 58, 5-17. [CrossRef]

31. Van Houten, Y.M.; Hoogerbrugge, H.; Knapp, M. Potential of Pronematus ubiquitus to control tomato russet mite, Aculops lycopersici. IOBC/WPRS Bull. 2020, 149, 87-92.

32. Baradaran, P.; Arbabi, M. Population abundance of Pronematus ubiquitus (McGregor, 1932) (Acari: Tydeidae) on different fig varieties. J. Entomol. Res. 2009, 1, 177-183.

33. Dean, H.A. Predators of Oligonychus pratensis (Banks), Tetranychidae. Ann. Entomol. Soc. Am. 1957, 50, 164-165. [CrossRef]

34. McCoy, C.W.; Selhime, A.G.; Kanavel, R.F. The Feeding Behavior and Biology of Parapronematus acaciae (Acarina: Tydeidae). Fla. Entomol. 1969, 52, 13. [CrossRef]

35. Knop, N.F.; Hoy, M.A. Biology of a tydeid mite, Homeopronematus anconai (n. comb.) (Acari: Tydeidae), important in San Joaquin valley vineyards. Hilgardia 1983, 51, 1-30. [CrossRef]

36. Knop, N.F.; Hoy, M.A. Factors Limiting the Utility of Homeopronematus anconai (Acari: Tydeidae) in Integrated Pest Management in San Joaquin Valley Vineyards. J. Econ. Entomol. 1983, 76, 1181-1186. [CrossRef]

37. Hessein, N.A.; Perring, T.M. The importance of alternate foods for the mite Homeopronematus anconai (Acari: Tydeidae). Ann. Entomol. Soc. Am. 1988, 81, 488-492. [CrossRef]

38. Pijnakker, J.; Vangansbeke, D.; Duarte, M.; Moerkens, R.; Wäckers, F.L. Predators and Parasitoids-in-First: From Inundative Releases to Preventative Biological Control in Greenhouse Crops. Front. Sustain Food Syst. 2020, 4, 245. [CrossRef]

39. Benson, C.M.; Labbe, R.M. Exploring the Role of Supplemental Foods for Improved Greenhouse Biological Control. Ann. Entomol. Soc. Am. 2021, 114, 302-321. [CrossRef]

40. Van Rijn, P.C.J.; van Houten, Y.M.; Sabelis, M.W. How plants benefit from providing food to predators even when it is also edible to herbivores. Ecology 2002, 83, 2664-2679.

41. Pijnakker, J.; Arijs, Y.; de Souza, A.; Cellier, M.; Wäckers, F. The use of Typha angustifolia (cattail) pollen to establish the predatory mites Amblyseius swirskii, Iphiseius degenerans, Euseius ovalis and Euseius gallicus in glasshouse crops, Integrated Control of Plant-FeedingMites. IOBC/WPRS Bull. 2016, 120, 47-52.

42. Labbé, R.M.; Gagnier, D.; Kostic, A.; Shipp, L. The function of supplemental foods for improved crop establishment of generalist predators Orius insidiosus and Dicyphus hesperus. Sci. Rep. 2018, 8, 17790. [CrossRef] [PubMed] 
43. Brenard, N.; Sluydts, V.; Christianen, E.; Bosmans, L.; De Bruyn, L.; Moerkens, R.; Liers, H. Biweekly supplementation with Artemia spp. cysts allows efficient population establishment by Macrolophus pygmaeus in sweet pepper. Entomol. Exp. Appl. 2019, 167, 406-414. [CrossRef]

44. Hoogerbrugge, H.; van Houten, Y.; van Baal, E.; Bolckmans, K. Alternative food sources to enable establishment of Amblyseius swirskii (Athias-Henriot) on chrysanthemum without pest presence. IOBC/WPRS Bull. 2008, 32, 79.

45. Pirayeshfar, F.; Safavi, S.A.; Sarraf Moayeri, H.R.; Messelink, G.J. The potential of highly nutritious frozen stages of Tyrophagus putrescentiae as a supplemental food source for the predatory mite Amblyseius swirskii. Biocontrol Sci. Technol. 2020, 30, 403-417. [CrossRef]

46. Pirayeshfar, F.; Safavi, S.A.; Moayeri, H.R.S.; Messelink, G.J. Provision of astigmatid mites as supplementary food increases the density of the predatory mite Amblyseius swirskii in greenhouse crops, but does not support the omnivorous pest, western flower thrips. BioControl 2021, 66, 1-12. [CrossRef]

47. Muñoz-Cárdenas, K.; Ersin, F.; Pijnakker, J.; van Houten, Y.; Hoogerbrugge, H.; Leman, A.; Janssen, A. Supplying high-quality alternative prey in the litter increases control of an above-ground plant pest by a generalist predator. Biological control 2017, 105, 19-26. [CrossRef]

48. Li, L.; Jiao, R.; Yu, L.; He, X.Z.; He, L.; Xu, C.; Zhang, L.; Liu, J. Functional response and prey stage preference of Neoseiulus barkeri on Tarsonemus confusus. System. Appl. Acarol. 2018, 23, 2244-2258. [CrossRef]

49. Vangansbeke, D.; Duarte, M.V.; Merckx, J.; Benavente, A.; Magowski, W.L.; França, S.C.; Wäckers, F.L. Impact of a tarsonemid prey mite and its fungal diet on the reproductive performance of a predatory mite. Exp. Appl. Acarol. 2021, 83, 313-323. [CrossRef]

50. Farfan, M.A.; Coffey, J.; Schmidt-Jeffris, R.A. Evaluation of Tarsonemus bilobatus and Podosphaera xanthii as suitable resources for Proprioseiopsis mexicanus in cucurbit systems in the Southeast USA. Exp. Appl. Acarol. 2021, 85, 31-40. [CrossRef]

51. Crawley, M.J. The R Book; John Wiley \& Sons Ltd.: Chichester, UK, 2007; p. 950.

52. Lenth, R. Least-Squares Means: The R Package lsmeans. J. Stat. Softw. 2016, 69, 1-33. [CrossRef]

53. Core Team, R. R: A Language and Environment for Statistical Computing; R Foundation for Statistical Computing: Vienna, Austria, 2018.

54. Castagnoli, M.; Simoni, S.; Nachman, G. Short-term changes in consumption and oviposition rates of Neoseiulus californicus strains (Acari: Phytoseiidae) after a diet shift. Exp. Appl. Acarol. 2001, 25, 969-983. [CrossRef]

55. Perring, T.M.; Lackey, L.J. Temperature and humidity effects on mortality and pre-adult development of two Phytoseiulus persimilis strains (Acari: Phytoseiidae). Int. J. Acarol. 1989, 15, 47-52. [CrossRef]

56. Samaras, K.; Pappas, M.L.; Fytas, E.; Broufas, G.D. Pollen suitability for the development and reproduction of Amblydromalus limonicus (Acari: Phytoseiidae). Biocontrol 2015, 60, 773-782. [CrossRef]

57. Van Rijn, P.C.J.; Tanigoshi, L.K. Pollen as food for the predatory mites Iphiseius degenerans and Neoseiulus cucumeris (Acari: Phytoseiidae): Dietary range and life history. Exp. Appl. Acarol. 1999, 23, 785-802. [CrossRef]

58. Bohs, L. Transfer of Cyphomandra (Solanaceae) and its species to Solanum. Taxon 1995, 44, 583-587. [CrossRef]

59. Buchmann, S.L.; Hurley, J.P. A biophysical model for buzz pollination in angiosperms. J. Theor. Biol. 1978, 72, 639-657. [CrossRef]

60. Van Ravestijn, W.; Van der Sande, J. Use of bumblebees for the pollination of glasshouse tomatoes. In VI International Symposium on Pollination (1990, August) ISHS. Acta Hortic. 1991, 288, 204-212. [CrossRef]

61. Poulton, J.L.; Koide, R.T.; Stephenson, A.G. Effects of mycorrhizal infection and soil phosphorus availability on in vitro and in vivo pollen performance in Lycopersicon esculentum (Solanaceae). Am. J. Bot. 2001, 88, 1786-1793. [CrossRef] [PubMed]

62. Firon, N.; Shaked, R.; Peet, M.M.; Pharr, D.M.; Zamski, E.; Rosenfeld, K.; Pressman, E. Pollen grains of heat tolerant tomato cultivars retain higher carbohydrate concentration under heat stress conditions. Sci. Hortic. 2006, 109, 212-217. [CrossRef]

63. Lefebvre, D.; Pierre, J. Hive weight as an indicator of bumblebee colony growth. J. Apicult. Res. 2006, 45, 217-218. [CrossRef]

64. English-Loeb, G.; Norton, A.P.; Gadoury, D.M.; Seem, R.C.; Wilcox, W.F. Control of Powdery Mildew in Wild and Cultivated Grapes by a Tydeid Mite. Biol. Control 1999, 14, 97-103. [CrossRef]

65. English-Loeb, G.; Norton, A.P.; Gadoury, D.; Seem, R.; Wilcox, W. Biological control of grape powdery mildew using mycophagous mites. Plant Dis. 2007, 91, 421-429. [CrossRef]

66. Pappas, M.L.; Steppuhn, A.; Broufas, G.D. The role of phytophagy by predators in shaping plant interactions with their pests. Commun. Integr. Biol. 2016, 9, e0127251. [CrossRef] [PubMed]

67. Travis, J.; Keen, W.H.; Juilianna, J. The role of relative body size in a predator-prey relationship between dragonfly naiads and larval anurans. Oikos 1985, 45, 59-65. [CrossRef]

68. Emmerson, M.C.; Raffaelli, D. Predator-prey body size, interaction strength and the stability of a real food web. J. Anim. Ecol. 2004, 73, 399-409. [CrossRef]

69. Pappas, M.L.; Xanthis, C.; Samaras, K.; Koveos, D.S.; Broufas, G.D. Potential of the predatory mite Phytoseius finitimus (Acari: Phytoseiidae) to feed and reproduce on greenhouse pests. Exp. Appl. Acarol. 2013, 61, 387-401. [CrossRef] [PubMed]

70. Samaras, K.; Pappas, M.L.; Pekas, A.; Wäckers, F.; Broufas, G.D. Benefits of a balanced diet? Mixing prey with pollen is advantageous for the phytoseiid predator Amblydromalus limonicus. Biol. Control 2021, 155, 104531. [CrossRef]

71. Asgari, F.; Moayeri, H.R.S.; Kavousi, A.; Enkegaard, A.; Chi, H. Demography and mass rearing of Amblyseius swirskii (Acari: Phytoseiidae) fed on two species of stored-product mites and their mixture. J. Econ. Entomol. 2020, 113, 2604-2612. [CrossRef] 